\title{
THE REORGANIZATION OF HIGH SCHOOL SCIENCE.
} Fred D. Barber, Illinois State Normal University, Normal, Ill.

The day has passed when it was pertinent to ask whether high school science needs reorganization; high school science is now being reorganized. While this reorganization has been taking place some of our scientific friends have been so engrossed in the daily routine of teaching science that they have had no time to glance over their spectacles and note the condition towards which high school science is rapidly drifting. Other of our scientific friends, more alert, have seen with unwilling eyes the drift of science but they have held firmly to the traditions of their own high school and college days; they have rebelled against every innovation; they have contended that the charge that much of our high school science teaching is a near failure from the point of view of the boy or girl is heretical and should be suppressed; they have compared those educators who asked that high school science be reorganized to the boy who cried "Wolf" when there was no wolf; they have said: "Leave high school science alone; we admit that the drift is bad at the present, but the organization and subject matter is the best possible; college and university men approve of it; apparent defects are due to poor teaching and we are about to remedy that defect."

This laissez faire attitude has been most pronounced in teachers of the biological and earth sciences; teachers of physical science have, as a rule, taken more kindly to the demand that high school science be modified, that it be adapted to the interests of high school pupils and to the needs of modern life.

Generally speaking, physical geography, physiology, zoology and botany have been the sciences taught in the first two years of the high school course. The laissez faire attitude of the teachers of these subjects, coupled with the growing conviction that the reorganization of high school science must begin at the bottom of the high school science curriculum, is now leading rapidly to the elimination of these subjects from the high school curriculum and the substitution of other subjects which are believed by many to be better adapted to the needs and interests of the pupils in the early years of the high school. The extent to which these four science subjects have declined during the past fifteen years-especially during the past five years - will be seen by a study of the accompanying graphs and Table I. 


\section{TABLE I.}

Table showing per cent increase (bold face) or decrease (light face) during the five years from 1910 to 1915 in the percentage enrollment in the high school science subjects.

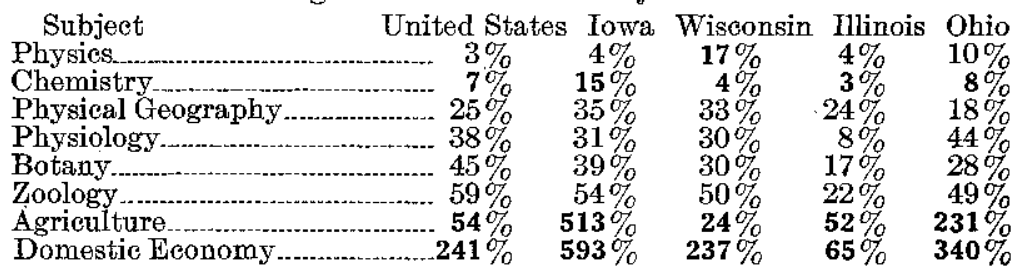

From these data it appears that physics is now nearly holding its own, that chemistry is making slight gains, that physical geography, physiology, botany and zoology are all rapidly losing ground and will soon disappear as high school subjects, or at least they will soon become unimportant subjects in the high school curriculum. It also appears that agriculture and domestic economy are everywhere making rapid gains. It is unfortunate that the reports of the Commissioner of Education, from which these figures are taken, do not show the part which general science is taking in this realignment of high school science. 1

It is interesting to note the approximate date at which we may expect physical geography, physiology, botany and zoology to disappear, or practically disappear, from the high school curriculum if their decline continues at the rate indicated from 1910 to 1915 .

\section{TABLE II.}

Table showing approximate date at which the science subjects generally taught during the first two years of the high school curriculum may be expected practically to disappear, their places being taken by other subjects.

\begin{tabular}{|c|c|c|c|c|c|}
\hline Subject & United States & Iowa & Wisconsin & Illinois & Ohio \\
\hline hysical Geog & ..1930 & 1924 & 1925 & 1931 & 1937 \\
\hline gy. & 1923 & 1926 & 1927 & 1965 & 1920 \\
\hline & 1921 & 1923 & 1927 & 1939 & 192 \\
\hline & 1919 & 1919 & 1920 & 1933 & \\
\hline
\end{tabular}

It would probably be erroneous to conclude, however, that high school science as a whole is at the present time declining

\footnotetext{
1The High School Supervisor of West Virginis in his report for 1915-1916 gives the total enrollment in high school science subjects in that state as follows: Physios, 831; Chemistry, 992; Botany, 738; Agriculture, 1431; Biology, 2194; and General Science, 1133.

A report of the Committee on Science in the High School of Tomorrow, given before the Central Association of Science and Mathematics Teachers, at Columbus, Ohio, November 30,1917 , shows in thirty-six large high schools in the Upper Mississippi Valley, having a total enrollment of 42,107 students, the following percentage enrollment in the sciences: Chemistry, $10.5 \%$; Physics, $10 \%$; Botany, 4.9\%; Zoology, 2.3\%; General Science, $7.1 \%$; Physiography, $5.4 \% ;$ Physiology, $2.5 \%$.
} 
if we include as high school science àgriculture, domestic economy, general science and general biology. A study of the reports of the Commissioner of Education for the past twenty years, incomplete though the reports are, leads to the conclusion that the total percentage enrollment in high school science subjects did decline from about 1900 to 1910 but from 1910 to 1915 there was a slight increase.

An analysis of the nature and significance of these shifts in our high school science curriculum is important. It seems fair to presume that, in a large measure, physical geography and physiology have given place to general science as the first-year-science course. Likewise, it is apparent that botany and zoology have given place to general biology in many schools in certain states and to agriculture in many schools in many states. Domestic economy, without doubt, has displaced the older sciences in many cases.

Why were these shifts made? Was it mere caprice, a desire on the part of teacher or pupil, or both, to try something new or different? Or is there a deep-lying conviction held by superintendents, principals, science teachers, and educators in general that the science courses which have been generally offered during the first two years of the high school curriculum are not well adapted to that purpose?

The accompanying graphs show that for some years before the advent of agriculture, domestic economy, and general science, all of the old recognized sciences were suffering a rather rapid decline. The truth is that all of the old recognized sciences failed some years ago to command the respect of students of education when regarded as educative materials which would best equip the pupil to take his place as a prosperous and self-respecting citizen in this twentieth-century world.

The following five graphs show the percentage of the total number of the public high schools of the United States and in Iowa, Wisconsin, Illinois, and Ohio which were enrolled in the various subjects indicated in 1900, 1905, 1910 and $1915 .^{2}$

In a measure, teachers and textbook writers of the physical sciences began to recognize the defects in the methods and

2Note: The data from which these graphs were made are to be found as follows:

Summary for the United States from 1890 to 1915, p. 487, Vol. 2, Report of the Commissioner of Education for 1916 .

For the various states for 1900 , pp. 2138-2139, Vol. 2, Report of Commisioner of Education for 1899-1900.

For the various states for 1905 , pp. 8324833, Vol. 2, Report for 1905 .

For the various states for 1910, pp. 1182-1184, Vol. 2 , Report for 1910 .

For the various states for 1915, pp. 500-503, Vol. 2, Report for 1916. 
materials of high school physics and chemistry some years ago. Some of the recent textbooks and considerable of the teaching bear evidence of a conscientious effort to make these courses more practical, more worth while and more interesting to the pupil. While there is unlimited room for further improvement, yet the changes already effected have been partly responsible for the check in the decline in percentage enrollment in these subjects.

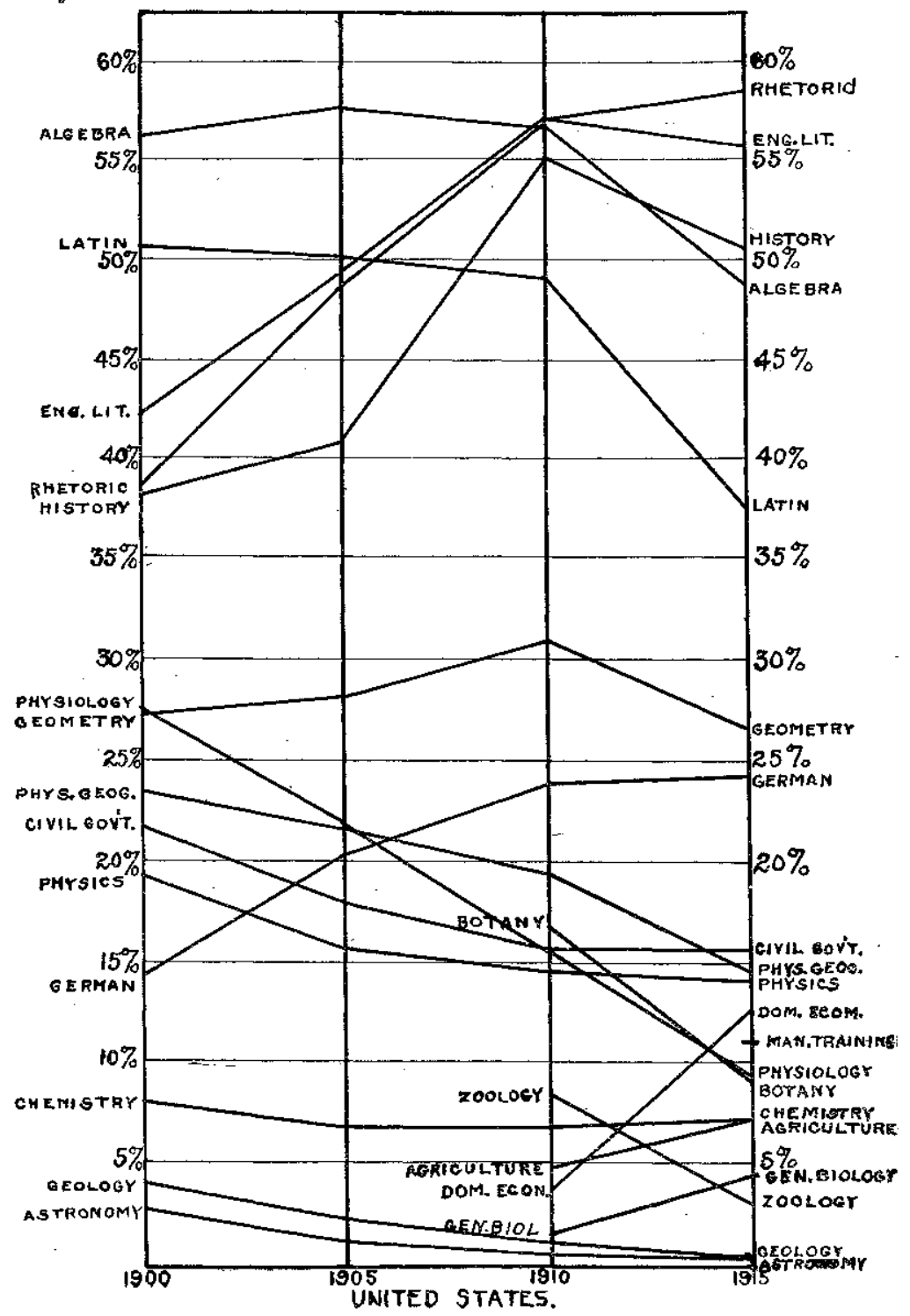


- In rather marked contrast with the attitude of the more progressive teachers of the physical sciences is the laissez faire attitude of many of the most influential leaders among the teachers of the biological sciences. One has but to study the addresses given at the educational meetings of the past fifteen years, to read the articles contributed to our educational journals, and to compare the resolutions adopted by the various biological

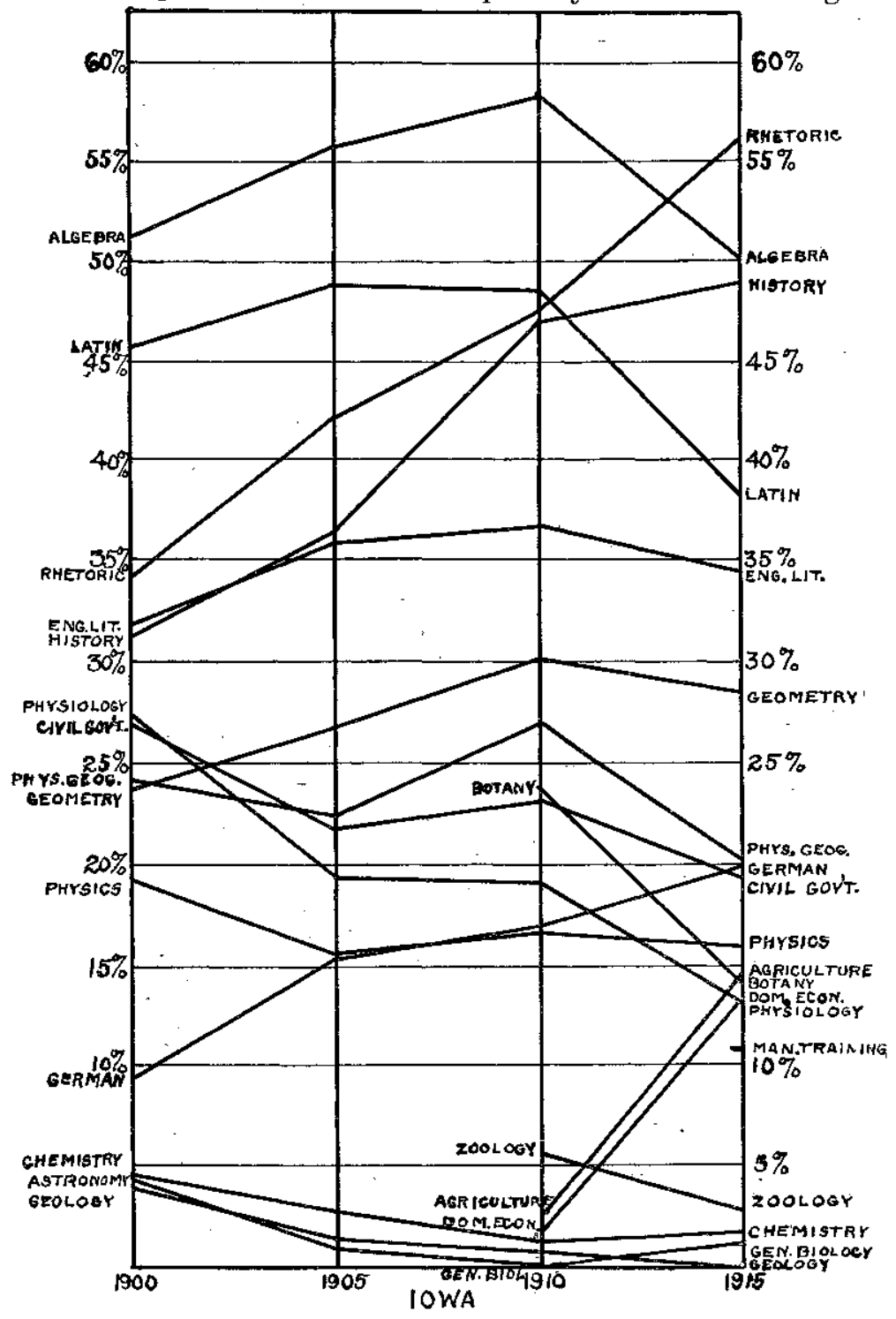


and physical science sections of our educational associations to note elearly this different attitude. There is little doubt that the attitude taken by the teachers of those sciences usually given in the first two years of the high school has been, in a large measure, responsible for the changes now taking place.

If the teachers of physical geography, physiology, botany and zoology, and especially the writers of the texts used, had

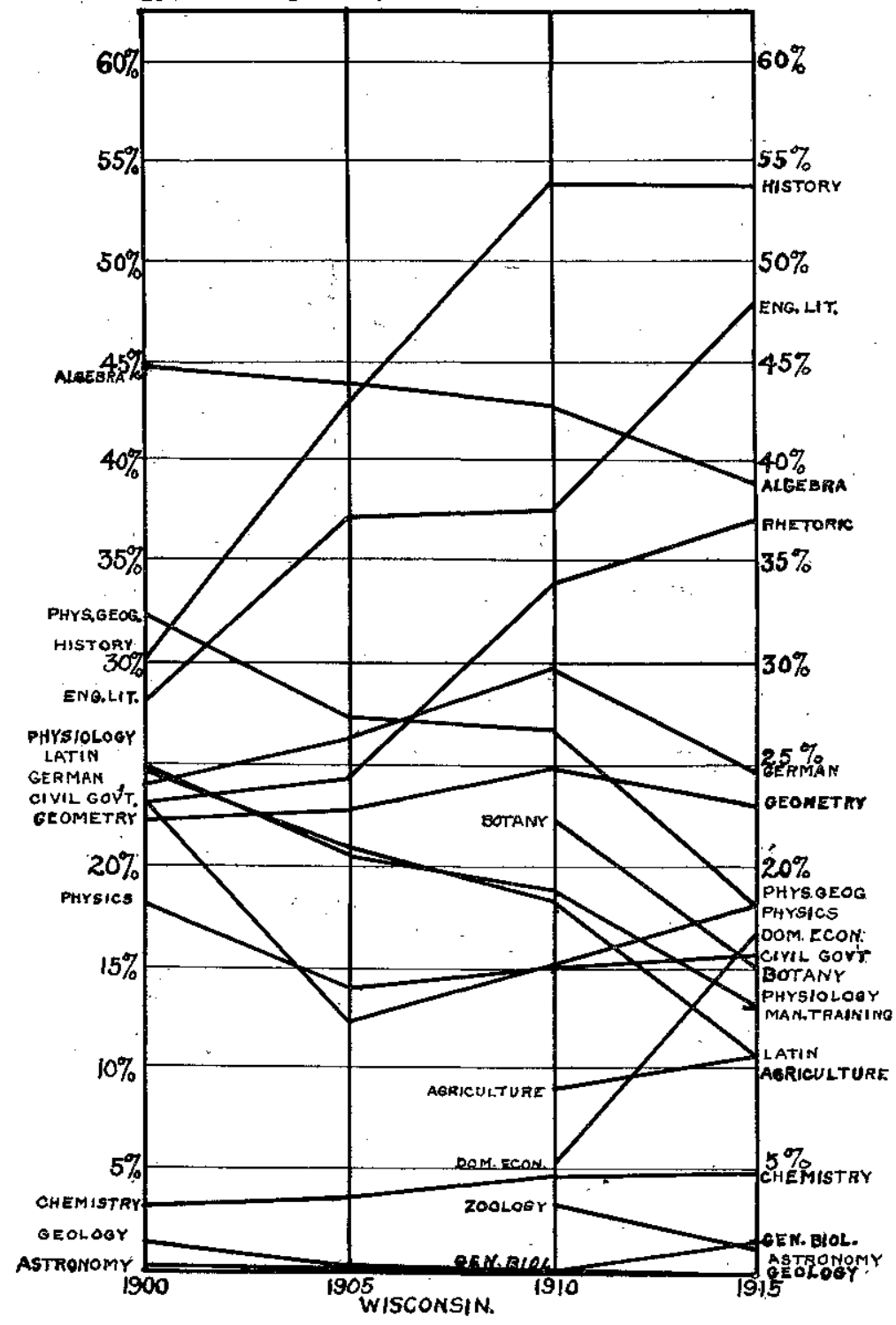


found a way of so modifying those courses some years ago as to make them appeal to the pupils as being more worth while and appeal to superintendents and principals as being of higher educational value, it is doubtful if general science, agriculture and domestic economy would ever have made much progress in displacing them. Many courses offered in agriculture and domestic economy belong in the later years of the

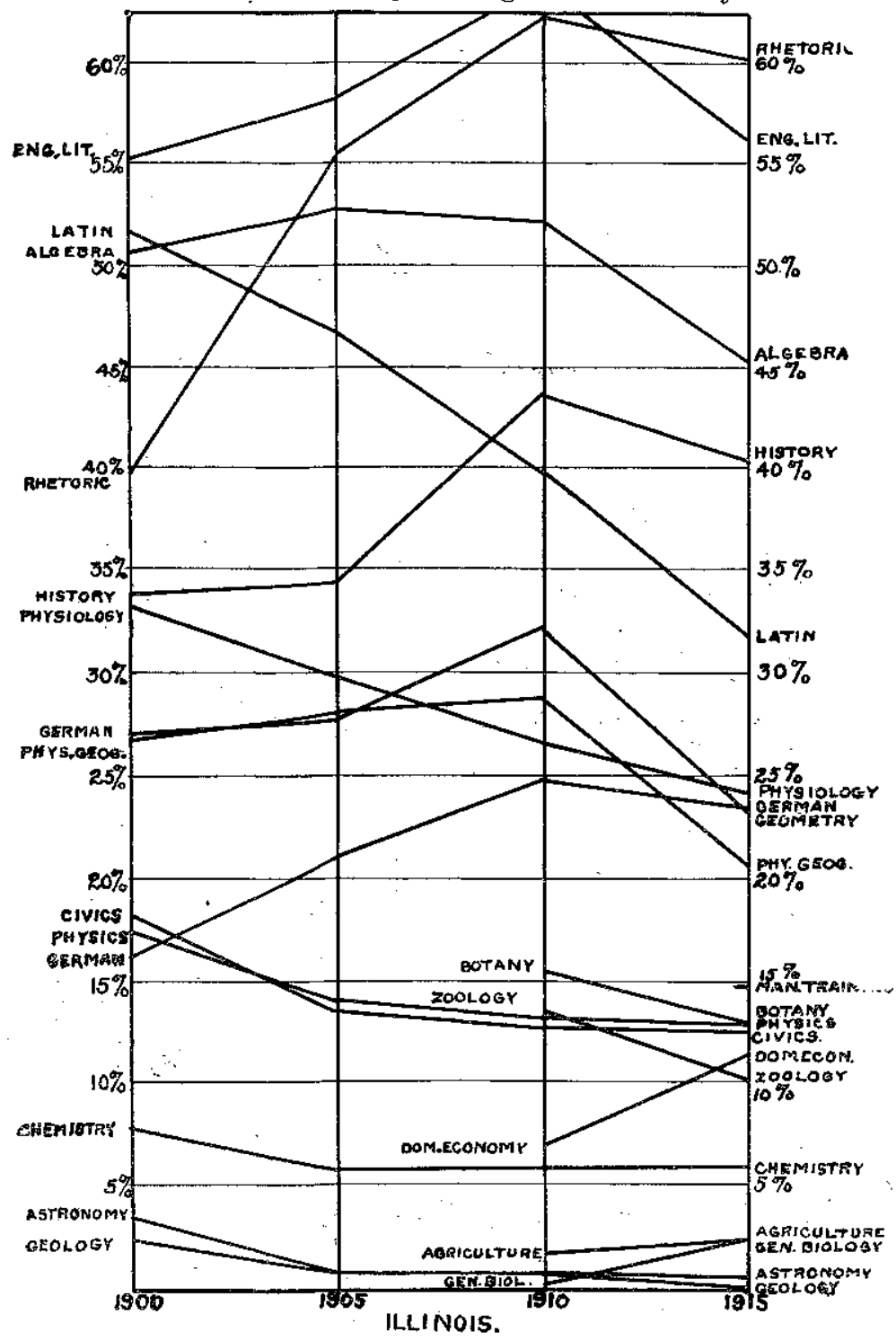


high school curriculum; such courses presuppose a knowledge of certain principles of science. Had the courses offered in the first two years really afforded the proper foundation for the study of agriculture and domestic economy, I am convinced that in our better school systems these two new "applied sciences" would have been placed farther up in the course, presumably displacing physics and chemistry.

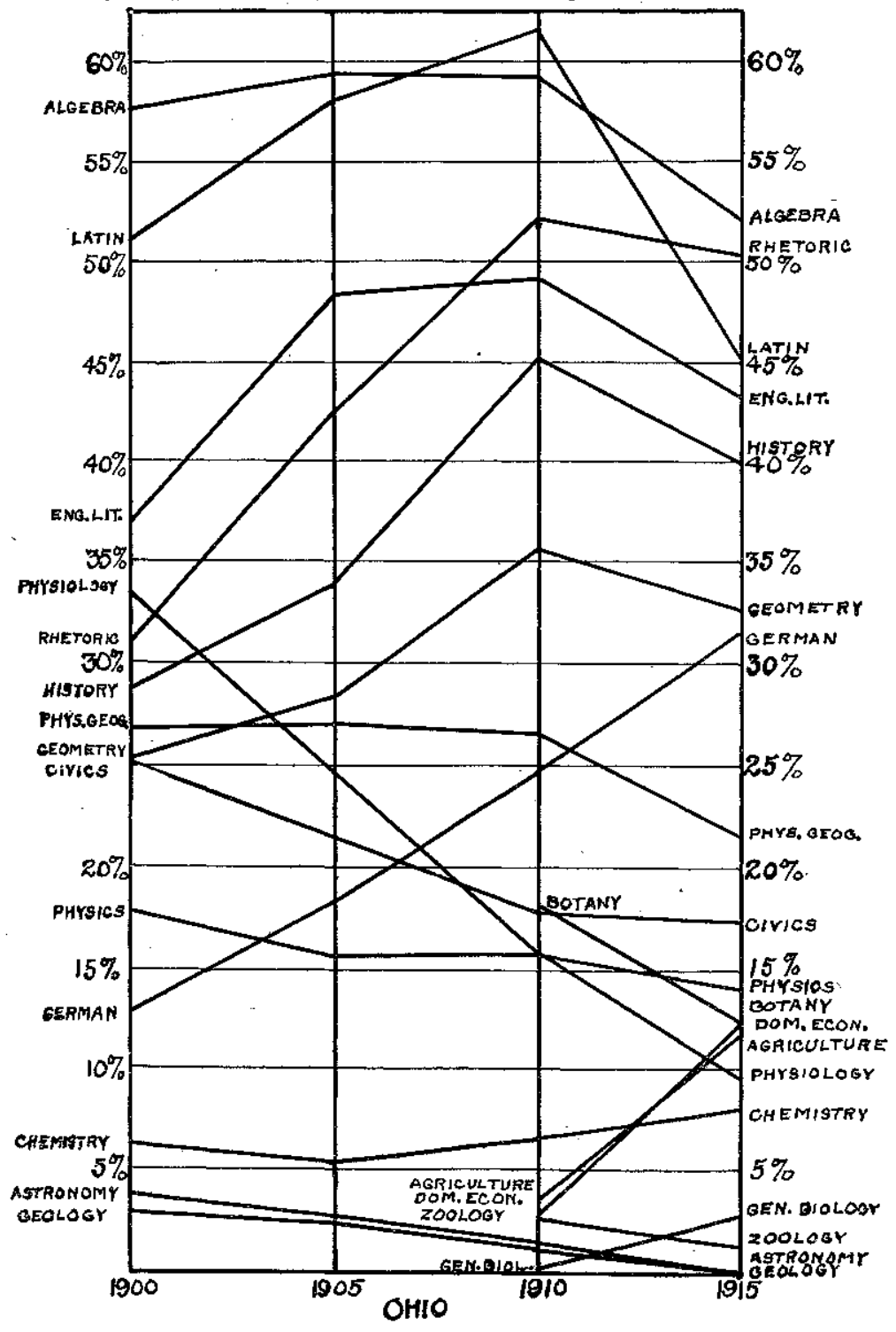




\section{A Condition, not a Theory.}

Our scientific friends who have been given to jeering at agriculture, domestic economy and general science as being "near science" and the "offspring of soft pedagogy" are now face to face with a condition, not a theory. Whether we classify these new subjects as science subjects or not, the fact remains that they have come to stay. With the departure of physical geography, physiology, botany and zoology from the eurriculum of the high school these new subjects will receive more attention and will be better taught. If these new subjects, as they are at present taught, lack some of the elements which gave to the older subjects greater educational value, it behooves the devotees of "pure science" to bend their best efforts towards helping so to shape up future high school science courses that those elements may be preserved. It is no secret that many students of education who have looked with favor upon the introduction of agriculture and domestic economy into the high school curriculum feel that the substitution of these courses, as they are frequently taught, for the old line science courses is a doubtful proceeding.

Nature of the Readjusted High School Science.

In the readjustment of high school science we should endeavor to preserve the best elements to be found in the old regime of special science and incorporate them with the best elements of the new regime of applied science. The old courses were not altogether bad; the new courses are not altogether good. Reorganized high school science should incorporate the elements of worthwhileness and interest from the new courses with some of the breadth of view and much of the scholarly attainment claimed for the old courses. If a course of science instruction extending from the seventh or eighth grade through the twelfth grade can be so organized and so taught as to attain these ends - and there is no apparent reason why this can not be done-then the reorganization of high school science will have been well worth while.

There can be but little question about the older sciences having afforded an insight into the historical significance of science and into the traditional man-made units of human knowledge concerning nature which the applied sciences will never give. It may be debatable whether the older sciences necessarily afforded a better opportunity for mental training, a claim insisted upon by the adherents of "pure science." Possibly it is inevitable 
that a newly organized subject shall lack, to a considerable degree, the conciseness and exactness which characterizes a subject which has been decades if not centuries in developing. It is this element of conciseness and exactness so manifest in the dead languages and in mathematics which gave those subjects for many years the reputation of being of the greatest educational value. Moreover, the teaching of such a static subject largely becomes a matter of imitation. The body of subject matter to be covered is well defined; the method of instruction is largely predetermined; the beginning teacher can do fairly well if he but follow closely in the footsteps of his own teacher. No such slavish imitation will produce acceptable results when applied to a developing, dynamic subject such as agriculture, domestic economy or general science. These subjects are in their formative stage and will remain so for many years to come.

\section{A Danger to be AvoIDed.}

The disrepute into which agriculture and domestic economy have fallen in the eyes of scientists lies in the fact that in a multitude of cases these subjects have assumed chiefly the form of arts, not sciences. To substitute the art of agriculture or the art of cooking for a training in the fundamental principles of science is an educational error which can produce nothing less than a failure quite as serious as the failure of "pure science" in which the principles of science were taught abstracted from all settings of human welfare. The present tendencies to substitute courses in agriculture and domestic economy for all science courses hitherto offered in the first two years of the high school course can result in nothing short of revolt on the part of every educator who appreciates the fact that all progress along material lines rests finally upon a knowledge of the fundamental principles of sciehce. The pendulum in swinging from "pure science" to the art of agriculture or the art of domestic economy has swung far past its normal position and is bound to return.

The proper reorganization of high school science consists in the establishment of a required stem course of science which shall incorporate the elements of historical significance and scholarship from the old regime with the elements of true worth and interest from the new regime. This course should be two years in length; it must deal with materials of universal value; it must present science in its psychological and pedago- 
gical order, not the logical order of special science; it must recognize the natural interests and the point of view of the pupil, not the interests and point of view of the trained scientist; it must afford the necessary foundation for an understanding of the principles involved in the art of agriculture and the art of domestic economy and at the same time it must provide the foundation for the further study of science in the college and university.

\section{The "Ordinary" Four-Year High School.}

The "ordinary" four-year high school is impossible of definition. Sometimes there are but two or three teachers; sometimes there are twenty-five or fifty teachers; some of these schools are strictly rural in character; some of them are strictly urban in character. While it is highly desirable that all high schools shall be standardized to the largest possible extent, we must allow rather wide margins in the science courses offered and the sequence in which those courses are taken. It is possible, however, to standardize the science curriculum so far as a two-year stem course is involved. The two-year stem course here advocated should be equally applicable to high schools of every type, the two-year high school, the three-year high school, the four-year high school, the rural high school and the urban high school. It will be equally applicable to every type of high school because it must deal with materials of universal interest and importance. The materials dealt with and the fundamental principles taught must be those which have universal application.

\section{Character of the Two-Yaar Stem Course.}

If this stem course in science is to meet the needs of all beginning students: it must meet the needs of the 95 per cent who never expect to go to college; it must meet the needs of the 5 per cent who do expect to go to college; it must meet the needs of the ever increasing percentage who will study agriculture as a preparation for life's work; it must meet the needs of the still more rapidly increasing percentage who will study domestic economy as a preparation for life's work; it must deal with materials which appeal to all high school pupils as being of such vital importance that an abiding interest in the study of science results; it must develop and make clear a large body of scientific principles which should constitute a portion of the equipment of every well educated citizen-the scientific pabulum of an independently thinking people. 
It must not be the end and aim of this stem course to make artisans in agriculture or in domestic economy of all our young people. It must give every pupil a glimpse of the history of the development of science and of scientific achievement at least from colonial days to the present time. They must see something of the influence of science upon the march of civilization. While the practical phases of science as it affects our lives here and now must be prominent in this two-year required course, it must also contain some of the cultural elements to be obtained from a survey of the historic past. Agriculture and domestic economy as they are now generally taught are as impossible of survival as the science to be taught in this stem course as were the old line sciences which are now passing out of the curriculum.

It matters little under what name or title this two-year course is listed; it is of imperative importance that it shall develop the foundation principles of science and do so in such a manner as to enlist the interest of the pupil and lead him into the habit of ever seeking the scientific explanation of common life-experiences. I know of no name or title more appropriate for such a course than to call it a two-year course in general science.

No matter under what name this two-year course is listed, its organization must be that of general science and not that of special science. It will be general science because it will disregard the artificial boundaries of special science; it will be general science because its units of instruction will be the natural, Creator-made units and not the artificial, man-made units of special science; it will have the general science organization because the principles taught will arise out of a study of the pupil's environment and not out of a study of types, many of which are entirely foreign to the pupil's present or future environment, as is the case with special science.

As a general plan for organizing the material of one's environment into a two-year course I suggest that a study of the home, the school and the street leading from the home to the school be made the first year; a study of an outer field comprising the animal and plant life found in the garden, in the orchard and in the field, together with such a study of aquatic life as may be available shall comprise the second year's work.

Suggested Two-Year Required Codrse in General Scievce:"

Naturally, physical science materials, such as lighting and heating systems, refrigeration, water supply and sewage disposal, the use of labor-saving machines, the weather, climate, 
ventilation, together with food and nutrition and microorganisms will comprise the course, and personal and community welfare will be the point of attack. The second course will reach out on every side for materials and will include a study of the plant and animal life found in the outlying environment of the school and community. It should also include a more comprehensive study of personal hygiene and community sanitation. The second year's course will, therefore, deal chiefly with biological materials although the influence of physical environment will everywhere be an important consideration.

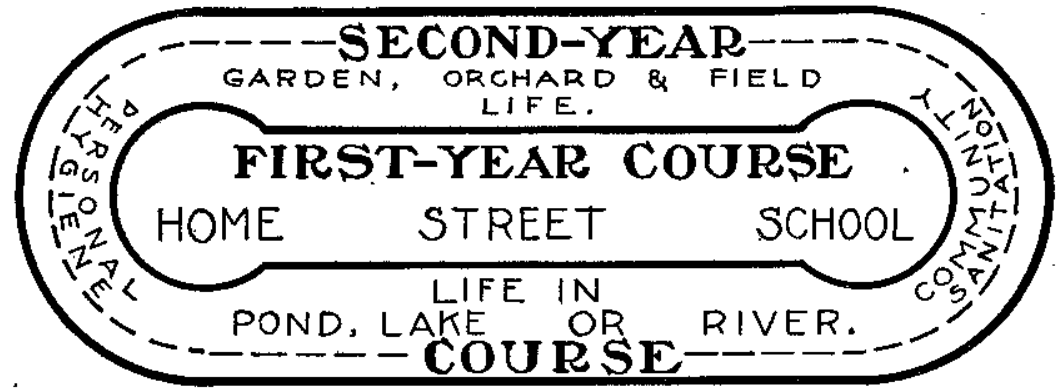

Much of the material which it is proposed to use in this two-year stem course is material which might properly be also studied in applied courses in agriculture and domestic economy. The manner of treatment, however, would be quite different from that given either in the old special science courses or in the newer applied science courses where the same material might be studied. For example, suppose that we consider the corn plant as the unite of instruction. In the special science, botany, no such unit of instruction would be tolerated. If corn were mentioned, it would first be mentioned, perhaps, when studying the unit germination; next, it might be mentioned many pages later when the unit roots was under consideration; its next mention might be under stems; thirty or forty pages later it might be mentioned under the unit leaves; later it might be mentioned under flowers; finally, it might again be mentioned under the unit fruits and seeds. Thus the study of this most important cultivated plant (which every pupil should study as a natural unit) is actually fragmentary and disjointed simply because special science refuses to recognize natural, Creatormade units but insists in serving up science in artificial, manmade units.

In agriculture, however, the corn plant and its environment is a logical unit because agriculture does deal with the 
natural or Creator-made units. But in applied agriculture the question raised is: How can we so select seed, how prepare the seed bed and cultivate the crop that we can secure more bushels of corn from an acre of land? The study of corn thus becomes more or less a study of the art of corn raising. Of course, the matter of insect pests will necessarily arise and so the study of corn will introduce some study of zoology, as will also the study of the preparation of the seed bed and the cultivation of the corn introduce some study of soil physics and weather and climate. Agriculture is necessarily general science and not special science so far as it is science at all.

In this stem course of general science with which we are now concerned, the purpose is somewhat different and therefore the attack and development is different. Here the question might well be: How does corn serve mankind, and how has it served him in the past? How does it grow? What is its natural environment? The technical and detailed study of producing it more cheaply or in greater abundance or of improving its quality may well be left for development in the course in agriculture; only those phases should be presented in this required course in general science which have to do with an understanding of corn, its nature, its natural environment, its cultivation and its uses - those phases which should be the possession of every well-educated citizen. That the prevailing methods of cultivation may be improved and that the corn plant is subject to climatic conditions, to diseases and to insect pests should be matters of common knowledge but the detailed diseussion of these points should never be made the chief characteristics of a study of corn in a science course required of all high school pupils.

If we turn to the materials treated in domestic economy we find a similar situation. Everybody should know certain truths concerning foods and nutrition but.we may safely leave to the class in domestic science the study of the art of cooking foods and much of the sciance involved in their preparation. Everybody is interested in food values and in the comparative costs of foods but we are willing that the detailed study of food values and balanced rations shall be taught in the domestic science class as well as the art of setting the table, arranging the knives, forks and spoons and a multitude of other details.

It seems perfectly clear to me that there is a great body of science material dealing with the environment of all high school students which has practically uniform significance in their lives. This material; therefore, is of equal value to all high 
school students; it is also nearly equally accessible to them. The basic course in high school science must deal with this body of science materials found in the environment of the pupils and it must develop out of a study of this material the principles of science which have universal significance.

\section{Advantages of a Generally Adopted Basic Course.}

From an administrative point of view it is clearly advisable that all high schools adopt a uniform science curriculum so far as it is possible to do so without sacrificing the interests and welfare of the pupils. Such a plan, if generally adopted, would enable the pupils to do two years of science study in the twoyear or the three-year high school and then complete the course in a four-year high school without loss. It would lessen expense and confusion in the large four-year high school by eliminating the need of differentiated science courses in the first two years. If such a course were required of all pupils in the first two years of the high school it would eliminate confusion and loss of time sometimes occasioned by pupils changing from one prescribed course to another within the same high school. Finally, I believe that colleges and universities could more easily adapt their entrance requirements and the first courses they offer to such a uniform preparation than they can to the extremely varied preparation which applicants for admission now offer.

\section{Elective Science Courses.}

The two-year required basic course in science must not be the only science course offered. In every rural high school courses in agriculture should be offered; in practically all high schools courses in domestic economy should be offered. Inasmuch, however, as the basic course will deal largely with materials which are closely related to the materials utilized in agriculture and domestic economy courses, these special courses may be shortened materially. Most high schools will also offer courses in special science, such as" physical geography, physiology, general biology, physies and chemistry. The extent to which these elective courses can be offered will be determined by the facilities of the school.

Even the special science courses in the high school of tomorrow must undergo readjustment. Probably they will still have the special science organization, i. e., the units of instruction will be the artificial, man-made units and the principles will be developed through the study of the most pronounced types; 
still it is inevitable, I believe, that they will treat less of the theoretical aspects of science and more of the practical aspects. After having studied the practical aspects of science for two years in the general science course, pupils will demand that their later science courses have a much stronger bearing upon the practical, upon the here and now, than has been the case with any of our special science courses in the past. Many years of experience have taught me that pupils who have been trained in the study of applied science are rarely if ever satisfied unless the relation of the scientific principle to human welfare is made prominent.

\section{Scinnce in the Coming Junior High School.}

Slowly but surely the 6-3-3 plan of organization of the public school is gaining ground. Eventually the junior high school will become an important reality. When that time comes we may hope to see science taught with success in the seventh and eighth grades. Properly trained teachers and properly equipped laboratories will be available. The seventh year may then well be devoted to nature study during the fall and spring months and to physiology and hygiene during the winter months. The first year's work of the proposed two-year course in general science can be done in the eighth year and the second year's work can be done in the ninth year. This will leave three years to be devoted to courses in agriculture, domestic economy or special science courses as they may be elected.

\section{To High School Science Teachers.}

Is it not worth while for high school science teachers, principals and superintendents to use every influence towards introducing some uniformity into our high school science curriculum? Is it not time that science teachers and high school principals should awaken to a realization of the chaotic condition into which high school science has been plunged? Are science teachers and principals willing that high school pupils shall be deprived of all science training during the first two years of the course except such as they may secure from the ordinary courses in agriculture and domestic economy?

I believe that this is an opportune time for all teachers who are interested in high school science and who appreciate its value as a vital factor in education to get together, forget their allegiance to some pet field of science, and unite upon some $c^{\text {ommon plan for the placing of high school science in its rightful }}$

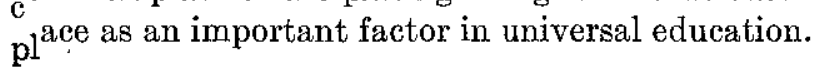

